\title{
Do Women Have Better Hearing Than Men?
}

\author{
Yong-Ho Park (D) \\ Department of Otolaryngology-Head and Neck Surgery, Brain Research Institute, Chungnam National University College of Medicine,
}

Daejeon, Korea

Men and women are biologically distinct. Their body structures and hormonal patterns are quite different, which implies the presence of clear functional differences. In recent reports, distinct immune responses have been described in men and women. These are presumed to contribute to differences between men and women in immune responses concerning various autoimmune diseases, malignancies, and infectious diseases. Therefore, it is essential to consider sex as a biological variable in the context of scientific research [1].

Recently, Kim et al. [2] reported that ovarian removal itself did not increase susceptibility to noise-induced hearing loss in an animal model, although administration of estrogen could improve hearing recovery and reduce hair cell loss in the cochlea after noise exposure. On the basis of those findings, it is important to consider whether there are hearing-related differences between men and women. Liu et al. reported that men experience more frequent deafness or serious hearing difficulty than women, on the basis of a large meta-analysis [3]. Other reports have indicated that men are more sensitive than women to noise-induced hearing loss [4]. The mechanisms of hearing loss are complex and diverse, although they most commonly involve reactive oxygen species formation inside the cochlea and subsequent tissue damage (i.e., loss of auditory hair cells and nerve fibers). For example, a study demonstrated differences between male and female animals in the regulation of cochlear blood flow, which is important in the context of hearing due to the effects of ischemia and oxidative stress [5].

In particular, the hormonal profile differs considerably between the sexes, and this influences organ function throughout the body. Several studies have investigated the effects of estrogen on hearing, and one found that hearing is influenced by the menstrual cycle through changes in serum levels of estrogen and progesterone [6]. Furthermore, attempts have been made to maintain hearing in post-menopausal women by administering estrogen hormone replacement therapy (HRT), but no studies have shown a protective effect against age-related hearing loss.
However, a report found that women receiving HRT had a higher risk of self-reported hearing loss [7]. The actions of estrogen are mediated through its interactions with two estrogen receptors (ER $\alpha$ and $E R \beta)$. In the mouse inner ear, the reported expression patterns of ER $\alpha$ and ER $\beta$ are broad and vary across cochlear areas (ER $\alpha$ : inner hair cells, outer hair cells, types I and II spiral ganglion neurons, Reissner's membrane, stria vascularis, and spiral ligament; ER $\beta$ : inner hair cells but not outer hair cells, Reissner's membrane, and stria vascularis, with lower expression in types I and II spiral ganglion neurons) [8]. In addition to the two canonical ERs (ER $\alpha$ and ER $\beta$ ), a family of estrogen-related receptors (ESRR or ERR: ERR $\alpha, E R R \beta$, and ERR $\gamma$ ) may also contribute to hearing physiology. Therefore, further research into the mechanism by which estrogen affects hearing will be clinically meaningful, and a follow-up study on HRT is highly anticipated. Women are more likely than men to receive estrogen HRT. Thus, it will be important to determine whether women also have a higher likelihood of hearing improvement.

\section{CONFLICT OF INTEREST}

No potential conflict of interest relevant to this article was reported.

\section{ORCID}

Yong-Ho Park https://orcid.org/0000-0003-2106-3791

\section{REFERENCES}

1. Klein SL, Flanagan KL. Sex differences in immune responses. Nat Rev Immunol. 2016 Oct;16(10):626-38.

2. Kim MT, Lee JH, Carpena NT, Lee MY, Chung PS, Jung JY. Estrogen replacement reduces hearing threshold shifts and cochlear hair cell

Copyright ( $) 2021$ by Korean Society of Otorhinolaryngology-Head and Neck Surgery.

This is an open-access article distributed under the terms of the Creative Commons Attribution Non-Commercial License (https://creativecommons.org/licenses/by-nc/4.0)

which permits unrestricted non-commercial use, distribution, and reproduction in any medium, provided the original work is properly cited. 
loss after acoustic overexposure in ovariectomized rats. Clin Exp Otorhinolaryngol. $2021 \mathrm{Feb}$;14(1):61-8.

3. Liu J,Wang D, Li X, Ningyu W. Association between sex and speech auditory brainstem responses in adults, and relationship to sex hormone levels. Med Sci Monit. 2017 May;23:2275-83.

4. Milon B, Mitra S, Song Y, Margulies Z, Casserly R, Drake V, et al. The impact of biological sex on the response to noise and otoprotective therapies against acoustic injury in mice. Biol Sex Differ. 2018 Mar; 9(1):12.

5. Reimann K, Krishnamoorthy G, Wier WG, Wangemann P. Gender differences in myogenic regulation along the vascular tree of the gerbil cochlea. PLoS One. 2011;6(9):e25659.

6. Kim SH, Kang BM, Chae HD, Kim CH. The association between serum estradiol level and hearing sensitivity in postmenopausal wom- en. Obstet Gynecol. 2002 May;99(5 Pt 1):726-30.

7. Curhan SG, Eliassen AH, Eavey RD, Wang M, Lin BM, Curhan GC. Menopause and postmenopausal hormone therapy and risk of hearing loss. Menopause. 2017 Sep;24(9):1049-56.

8. Simonoska R, Stenberg A, Masironi B, Sahlin L, Hultcrantz M. Estrogen receptors in the inner ear during different stages of pregnancy and development in the rat. Acta Otolaryngol. 2009 Nov;129(11): 1175-81. 